\title{
Micro CT Analysis of Geopolymer Composites
}

Totka Bakalova ${ }^{1}$, Marcela Kolínová ${ }^{\text {, Petr Louda }}{ }^{1,2}$

${ }^{1}$ Institute for Nanomaterials, Advanced Technologies and Innovation, Technical university of Liberec, Studentská 2 , 461

17 Liberec, Czech Republic, E-mail: totka.bakalova@tul.cz, marcela.kolinova@tul.cz, petr.louda@tul.cz

${ }^{2}$ Faculty of mechanical Engineering, Department of Material Science, Technical university of Liberec, Studentská 2, 461

17 Liberec, Czech Republic. E-mail: petr.louda@tul.cz

There are many situations when you need information about the internal structure of the materials. Computed Tomography (CT) is a non-destructive method of evaluating the internal structure, which was originally used for medical examination of the human body. Today it is already used in many different fields, where the aim is the examination of the internal structure of the material. Geopolymer is a term for all inorganic polymeric materials which are prepared from alumino-silicate materials by geopolymerization in alkaline environment at normal temperature and pressure. Computed tomography (CT) is an advanced method that allows the study of the structure based geopolymer composites with short fibers or nanoparticulate reinforcement.

Keywords: computerized tomography (CT), non-destructive method, internal structure, geopolymer

\section{Acknowledgment}

The results of this project LO1201 were obtained through the financial support of the Ministry of Education, Youth and Sports in the framework of the targeted support of the "National Programme for Sustainability $I$ " and the OPR\&DI project Centre for Nanomaterials, Advanced Technologies and Innovation CZ.1.05/2.1.00/01.0005 and by the Project Development of Research Teams of $R \& D$ Projects at the Technical University of Liberec CZ.1.07/2.3.00/30.0024.

The paper was supported in part by the project OP VaVpI „Innovative products and environmental technologies“, registration number CZ.1.05/3.1.00/14.0306.

\section{References}

[1] XIEM, N. T. (2011). Disertační práce, Možnosti průmyslového využití geopolymerních materialů v oblasti zpracování elektrárenského popílku, TUL, Liberec.

[2] BAKALOVA, T., KOLÍNOVÁ, M. (2014). Jemná mechanika a optika, č. 4/2014, Možnosti použití počítačové tomografie (CT) v technice, pp. 111 - 114, ISSN 0447-6441.

[3] DAVIDOVITS, J. (2008). Geopolymer chemistry \& application, Second Edition, Institute Géopolymèr, France.

[4] XIEM, N. T., LOUDA, P., KROISOVÁ, D. (2011). IXth International Conference Preparation of Ceramic Materials, 14 - 16th June 2011, Effect of curing on the mechanical properties of geopolymer mortar incorporating different fly ash content, pp. 89 - 93, ISBN: 978-80-553-0678-0, Slovakia.

[5] ZONGJIN, L., et al. (2004). Development of sustainable cementitious materials, International Workshop on Sustainable Development and Concrete Technology, China.

[6] LOUDA, P., KROISOVÁ, D., HUNG, T. D., XIEM, N. T. (2011). Vysokopevnostní geopolymerní kompozit, Publish No: 2011-24194.

[7] PALOMO, A., et al. (1999). Alkali activated fly ashes: Cement for the future Cement Concrete Res 29, pp. 1323 -1329 .

[8] RANGAN, R. V. (2007). Low-calcium fly ash based geopolymer concrete, Concrete construction Engineering handbook (2nd ed.), New York.

[9] HARDJITO, H., RANGAN R. V. (2005). Development and properties of low-calcium fly ash based geopolymer concrete. Research report GC1. Perth, Australia: Faculty of Engineering, Curtin University of Technology.

[10] SHUZHENG, Z., et al. (2004). Novel modification method for inorganic geopolymer by using water soluble organic polymers, Elsevier B. V, Vol. 58, Issues 7-8, pp. $1292-1296$.

[11] DUXSON, P., et al. (2007). The role of inorganic polymer technology in the development of 'green concrete, Cement and Concrete Research 37, pp. 1590 - 1597.

[12] DUXSON, P., et al. (2006) Thermal conductivity of metakaolin geopolymers used as a first approximation for determining gel interconnectivity, Ind. Eng. Chem. Res, 45 (23), pp. $7781-7788$. 
[13] PALOMO, A., et al. (2004). Chemical stability of cementitious materials based on metakaolin, Cem. Concr. Res. 29 (7), pp. $997-1004$.

[14] LEE, W. K. W., VAN DEVENTER, J. S. J. (2006). The effect of ionic contaminants on the early-age properties of alkali-activated fly ash-based cements, Cement Concrete Res. 32 (4), pp. 577 - 584.

\section{Paper number: M201495}

Copyright (C) 2014. Published by Manufacturing Technology. All rights reserved. 